Bangladesh J. Pl. Breed. Genet., 27(1): 17-23, 2014

\title{
COMBINING ABILITY ANALYSIS FOR DIFFERENT YIELD COMPONENTS IN MAIZE (Zea mays L.) INBRED LINES
}

\author{
F. M. A. Haydar and N. K. Paul
}

Department of Botany

University of Rajshahi, Rajshahi, Bangladesh

\begin{abstract}
The present study was carried out to determine the combining ability of yield and yield components by crossing six diverse maize inbred lines in a half diallel mating design. Fifteen $F_{1}$ progenies along with their six parents were planted in randomized complete block design with three replications. GCA to SCA ratios were less than one for plant height, cob diameter, cob length and number of kernels row/cob indicating a preponderance of additive over non additive gene action. The crosses $\mathrm{P}_{1} \times \mathrm{P}_{2}, \mathrm{P}_{3} \times \mathrm{P}_{5}$ and $\mathrm{P}_{5} \times \mathrm{P}_{6}$ were exhibited significant and positive SCA effects for yield and cob diameter, number of row/cob and number of grains/cob of yield contributing characters. The parents $\mathrm{P}_{1}\left(\mathrm{IL}_{4}\right), \mathrm{P}_{3}\left(\mathrm{IL}_{18}\right)$ and $\mathrm{P}_{5}\left(\mathrm{IL}_{23}\right.$ were good general combiner for grain yield and yield attributing characters. It can be concluded that these parental lines can be desirable parents for hybrids as well as for inclusion in breeding program, since they may contribute favorable alleles in the synthesis of new varieties.
\end{abstract}

Keywords: Crossing; combiner; alleles; maize; diallel

\section{INTRODUCTION}

Maize (Zea mays L.) is the most important cereal crop in the world after wheat (Triticum aestivum $\mathrm{L}$ ) and rice (Oryza sativa $\mathrm{L}$ ). It has great yield potential and attained the leading position among the cereals based on production as well as productivity (Keskin et al., 2005). It is the most important silage plant in the world because of its high yield, high energy forage produced with lower labor and machinery requirements than the other forage crops (Roth et al., 1995). Every part of the plant has economic value; the grain, leaves, stalk, tassel are used to produce hundreds of food and non-food products (Haddadi et al., 2012).

The cultivated area and production of maize is increasing day by day due to it's yield potentiality. High yield potentiality and its multipurpose use as food can reduce wheat production area and maize imports. Maize is also the most demandable cereal food of the poultry industry in Bangladesh (Zaman and Alam, 2013). So, maize can play an 
important role in increasing food production of Bangladesh. At present, the farmers are cultivating some imported hybrid maize varieties, but they are very expensive. So, we have to develop hybrid maize varieties. The nature and magnitude of gene action is an important factor in developing an effective breeding programme.

Combining ability studies provide information on the genetic mechanisms controlling the inheritance of quantitative traits and enable the breeders to select suitable parents for further improvement or use in hybrid breeding for commercial purposes. In biometrical genetics two types of combining abilities are considered i.e. general combining ability (GCA) and specific combining ability (SCA). General combining ability refers to the average performance of the genotype in a series of hybrid combinations and is a measure of additive gene action whereas; specific combining ability is the performance of a parent in a specific cross in relation to general combining ability (Sharief et al., 2009). SCA is due to genes showing non-additive effects (Sprague and Tatum, 1942). The objectives of the present study were to evaluate GCA and SCA effects of six maize inbred lines and their $\mathrm{F}_{1}, \mathrm{~s}$ in order to determine superior breeding lines and cross combinations.

\section{MATERIALS AND METHODS}

The genetic materials used in this experiment were six parents $\left(\mathrm{IL}_{4}=\mathrm{P}_{1}, \mathrm{IL}_{5}=\mathrm{P}_{2}, \mathrm{IL}_{18}=\mathrm{P}_{3}\right.$, $\mathrm{IL}_{10}=\mathrm{P}_{4}, \mathrm{IL}_{23}=\mathrm{P}_{5}$ and $\left.\mathrm{IL}_{1}=\mathrm{P}_{6}\right)$ and their $\mathrm{F}_{1}$ which were $\mathrm{P}_{1} \times \mathrm{P}_{2}, \mathrm{P}_{1} \times \mathrm{P}_{3}, \quad \mathrm{P}_{1} \times \mathrm{P}_{4}, \mathrm{P}_{1} \times \mathrm{P}_{5}$, $\mathrm{P}_{1} \times \mathrm{P}_{6}, \mathrm{P}_{2} \times \mathrm{P}_{3}, \mathrm{P}_{2} \times \mathrm{P}_{4}, \mathrm{P}_{2} \times \mathrm{P}_{5}, \mathrm{P}_{2} \times \mathrm{P}_{6}, \mathrm{P}_{3} \times \mathrm{P}_{4}, \mathrm{P}_{3} \times \mathrm{P}_{5}, \mathrm{P}_{3} \times \mathrm{P}_{6}, \mathrm{P}_{4} \times \mathrm{P}_{5}, \mathrm{P}_{4} \times \mathrm{P}_{6}$ and $\mathrm{P}_{5} \times \mathrm{P}_{6}$. The present investigation was carried out during 26 November 2013 and 28 November 2014 seasons at the experimental field, Department of Botany, University of Rajshahi, Bangladesh. Plants at flowering stage (just before anthesis) were selected and crossed in half diallel fashion from 26 November, 2013 to January, 2014 excluding reciprocals and to obtain the $F_{1}$ seeds. The $F_{1}$ seeds of all the crosses with their parents were planted in the field on 28 November, 2014 season for evaluation in a randomized block design with three replications. The experimental unit was a single row of $3.0 \mathrm{~m}$ long. Inter-plant and inter-row distances were 10 and $30 \mathrm{~cm}$, respectively. Fertilizers were applied at the rate of $250,125,120,45$ and $5 \mathrm{~kg} / \mathrm{ha}$ of $\mathrm{N}, \mathrm{P}_{2} \mathrm{O}_{2}, \mathrm{~S}$ and $\mathrm{Zn}$, respectively. Necessary intercultural operations and irrigation were done during the crop period to ensure normal growth and development of the plants.

Five plants from each row were randomly selected for recording data on the studied characters such as days to tasseling, days to silking, days to maturity, plant height $(\mathrm{cm})$, ear height $(\mathrm{cm})$, cob length $(\mathrm{cm})$, cob diameter $(\mathrm{cm})$, number of rows/cob, number of kernels/row, number of kernels/cob and grain yield/plant $(\mathrm{g})$. The combining ability analyses were carried out using Griffing's (1956) Method 2 Model II given in "Statistical and Biometrical Techniques in Plant Breeding by Sharma (1998) using CropStat (2007).The mean squares for GCA and SCA were tested against their respective error variances derived from ANOVA reduced to mean level. 


\section{RESULTS AND DISCUSSION}

The analysis of variance revealed highly significant difference for cob diameter, cob length, number of row/cob, number of kernels/cob and grain yield, indicating the existence of wider genetic variability among the lines. Both general combining ability (GCA) and specific combining ability (SCA) variances were found to be highly significant (Table 1) for all the characters studied which indicated that both additive and non-additive gene action played predominant role for the expression of these characters. Relative importance of GCA and SCA was calculated. In the present study GCA/SCA variance was observed to be unity for cob length, cob diameter and number of rows/cob indicating equal importance of both additive and non additive gene effects. The SCA component of variance was higher than GCA component of variance for the characters like plant height, cob diameter and number of rows/cob indicating the predominance of non-additive or dominant gene action. The influence of dominant type of gene action was also observed by Singh and Kumar (2008); Amiruzzaman et al. (2011) and Singh et al. (2012) in maize inbred lines.

Table 1. Mean square from the analysis of variance for combining ability of different characters in maize in a $6 \times 6$ half diallel cross

\begin{tabular}{|c|c|c|c|c|c|c|c|}
\hline $\begin{array}{l}\text { Source of } \\
\text { variation }\end{array}$ & $\mathrm{df}$ & DT & DS & DM & $\mathrm{PH}$ & $\mathrm{EH}$ & $\mathrm{CL}$ \\
\hline GCA & 5 & $15.009 * *$ & $10.473 * *$ & $185.502 * *$ & $146.110 * *$ & $706.221 * *$ & $11.733 * *$ \\
\hline $\mathrm{SCA}$ & 15 & $4.795 * *$ & $4.425 * *$ & $42.028 * *$ & $202.268 * *$ & $250.405 * *$ & $6.675 * *$ \\
\hline Error & 40 & 4.795 & 4.632 & 5.098 & 35.546 & 129.636 & 3.645 \\
\hline GCA:SCA & 0.33 & 3.159 & 2.366 & 4.414 & 0.721 & 2.820 & 1.758 \\
\hline \multicolumn{8}{|c|}{ Table 1. Contd. } \\
\hline $\begin{array}{l}\text { Source of } \\
\text { variation }\end{array}$ & df & $\mathrm{CD}$ & $\mathrm{NRC}$ & \multicolumn{2}{|c|}{ NKR } & NGC & GYP \\
\hline GCA & 5 & $4.024^{*}$ & 0.433 & \multicolumn{2}{|c|}{$94.069 * *$} & $12916.598 * *$ & $1035.173 * *$ \\
\hline SCA & 15 & $4.928 * *$ & 0.581 & \multicolumn{2}{|c|}{$12.116^{* *}$} & $3571.143 * *$ & $286.216 * *$ \\
\hline Error & 40 & 2.162 & 0.489 & \multicolumn{2}{|c|}{17.689} & 3376.707 & 270.629 \\
\hline GCA:SCA & 0.33 & 0.816 & 0.816 & \multicolumn{2}{|c|}{7.764} & 3.616 & 3.617 \\
\hline
\end{tabular}

*, ** indicated at $5 \%$ and $1 \%$ level of significance, GCA: General combining ability, SCA: Specific combining ability. DT: Days to tasseling, DS: days to silking, DM: days to maturity, PH: plant height, EH: ear height, CL: cob length, CD: cob diameter, NRC: number of rows/cob, NKR: number of kernels/row, NGC: number of grains/cob and GYP: grain yield/plant

Combining ability analysis revealed that estimates of SCA variances were higher than GCA variances for the characters like plant height, cob diameter and number of rows/cob under study, suggesting predominance of non-additive or dominant gene action for these characters. These results are in agreement with earlier reports of Pavan et al. (2011) and Singh et al. (2012) for number of kernels per row, number of kernels per ear, 100-grain weight and grain yield per plant, and Amiruzzaman et al. (2011) for quantitative like kernel yield per plant, number of kernels per ear and 1000-kernel 
weight. High magnitudes of SCA component were predominant indicating the dominance and epistatic interaction for these characters. The estimated ratio between GCA and SCA was more than unity indicating the predominance of additive gene action for most of the characters except plant height, cob diameter and number of rows/cob. Uddin et al. (2008) also reported predominance of non additive gene action in maize. Grain yield and its contributing characters were suggested to be controlled by additive and non additive gene actions in maize inbred lines.

\section{General Combining Ability of the Parents}

Due to importance of early maturity and lower values of days to silking; $\mathrm{P}_{4}$ which had significant negative GCA effects were considered as good combiners for this character. The estimate of GCA effects showed that the parents $\mathrm{P}_{1}, \mathrm{P}_{3}$ and $\mathrm{P}_{4}$ were good combiners for grain yield and yield attributing characters like days to maturity, ear height, number of kernels/row, number of grains/cob and grain yield plant( Table 2.). Result indicated that the parents possess high frequency of favorable genes for these characters. The estimates of GCA effects showed that the parent $\mathrm{P}_{1}$ was the best combiner of days to silking and maturity, ear height, grains/cob, grain yield and also for earliness. Parents $\mathrm{P}_{4}$ and $\mathrm{P}_{5}$ had significant positive GCA effects for ear height making them good combiners for improving the trait. Thus, the inbred lines which exhibited good general combining ability for at least one character can be used as donor parents for the accumulation of favorable genes. These findings are accordance with Khalil et al. (2010) and Singh et al. (2012) and Haddadi et al. (2012).

Table 2. General combining ability (GCA) effects for 11 yield and its related traits in maize

\begin{tabular}{lcccc|c|c}
\hline Inbreds & DT & DS & DM & PH & EH & CL \\
\hline GCA & 1.42 & 1.27 & $-4.45^{* *}$ & 0.39 & $-8.39 * *$ & -0.05 \\
$\mathrm{P}_{1}$ & -0.74 & -0.13 & $2.66 * *$ & 0.13 & -0.21 & -0.02 \\
$\mathrm{P}_{2}$ & -0.43 & -0.27 & $2.98 * *$ & -0.17 & -1.03 & 0.25 \\
$\mathrm{P}_{3}$ & $-3.55^{*}$ & $-2.49 *$ & $-5.40 * *$ & -0.20 & -0.89 & -0.20 \\
$\mathrm{P}_{4}$ & 0.45 & 0.11 & -0.58 & -0.25 & $7.13 * *$ & -0.06 \\
$\mathrm{P}_{5}$ & -0.16 & -0.49 & 0.79 & -0.24 & $3.39 * *$ & 0.07 \\
$\mathrm{P}_{6}$ & 0.35 & 0.34 & 0.42 & 1.11 & 2.12 & 0.36 \\
S.E(gi) & \multicolumn{7}{c}{} \\
\hline
\end{tabular}

\begin{tabular}{l|c|c|c|c|c}
\hline \multicolumn{6}{l}{ Contd. Table 2 . } \\
\hline Inbreds & CD & NRC & NKR & NGC & GYP \\
\hline GCA & 0.051 & 0.388 & -0.237 & $18.422^{* * *}$ & $-8.301^{* * *}$ \\
$\mathrm{P}_{1}$ & 0.336 & 0.132 & -0.846 & $7.419^{* *}$ & $-7.018^{* *}$ \\
$\mathrm{P}_{2}$ & -0.271 & 0.173 & 1.045 & $19.055^{* *}$ & 0.358 \\
$\mathrm{P}_{3}$ & 0.320 & -0.198 & -1.071 & $-15.88^{* *}$ & $3.178^{* *}$ \\
$\mathrm{P}_{4}$ & -0.373 & -0.252 & 0.789 & $2.703^{* *}$ & $8.877^{* *}$ \\
$\mathrm{P}_{5}$ & -0.063 & -0.242 & 0.311 & $-2.880^{* *}$ & $2.906^{* *}$ \\
$\mathrm{P}_{6}$ & 0.274 & 0.130 & 0.783 & 10.828 & 3.065 \\
S.E(gi) &
\end{tabular}

DT: Days to tasseling, DS: days to silking, DM: days to maturity, PH: plant height, EH: ear height, CL: cob length, CD: cob diameter, NRC: number of rows/cob, NKR: number of kernels/row, NGC: number of grains/cob and GYP: grain yield/plant 
Table 3. Specific combining ability (SCA) effects for 11 yield and its related traits in maize

\begin{tabular}{|c|c|c|c|c|c|c|c|c|c|c|c|}
\hline Crosses & DT & DS & DM & PH & $\mathrm{EH}$ & CL & $\mathrm{CD}$ & NRC & NKR & NGC & GYP \\
\hline $\mathrm{P}_{1} \times \mathrm{P}_{2}$ & $2.476^{*}$ & $4.757 * *$ & $2.244 *$ & $2.130 * *$ & $-7.487 * *$ & -0.07 & -0.102 & $7.61 * *$ & $3.034 * *$ & $56.096 * *$ & $15.880^{* *}$ \\
\hline $\mathrm{P}_{1} \times \mathrm{P}_{3}$ & 1.601 & 0.671 & $3.178 * *$ & $4.121 * *$ & $6.762 * *$ & 0.171 & $2.202 * *$ & 0.253 & -1.253 & $-11.127 * *$ & $-3.150 * *$ \\
\hline $\mathrm{P}_{1} \times \mathrm{P}_{4}$ & -0.203 & 0.614 & 0.192 & $-2.574 * *$ & $7.332 * *$ & 0.752 & -0.248 & $2.248^{*}$ & -0.324 & $3.251 * *$ & 0.920 \\
\hline $\mathrm{P}_{1} \times \mathrm{P}_{5}$ & 0.221 & $-2.343 * *$ & -0.270 & $-7.139 * *$ & $-9.197 * *$ & $2.202 *$ & $-3.147 * *$ & $3.398^{*}$ & $4.124 * *$ & $16.295^{* *}$ & $4.613 * *$ \\
\hline $\mathrm{P}_{1} \times \mathrm{P}_{6}$ & -1.201 & -0.384 & $7.163^{* *}$ & $-7.866 * *$ & $-5.590 * *$ & -0.822 & 0.741 & $-4.80^{* *}$ & 1.300 & $-5.745^{* *}$ & -1.626 \\
\hline $\mathrm{P}_{2} \times \mathrm{P}_{3}$ & 0.096 & $2.153 * *$ & $3.319 * *$ & $7.677 * *$ & $5.367 * *$ & $-3.17 * *$ & 1.173 & $-2.80 * *$ & -0.058 & $-6.360 * *$ & -1.800 \\
\hline $\mathrm{P}_{2} \times \mathrm{P}_{4}$ & 1.549 & 0.927 & 1.391 & $-7.871 * *$ & $6.191 * *$ & $4.02 * *$ & 0.296 & -0.457 & $-3.58 * *$ & $-32.514 * *$ & $-9.205^{* *}$ \\
\hline $\mathrm{P}_{2} \times \mathrm{P}_{5}$ & 0.054 & -0.254 & 0.981 & $-3.763 * *$ & $-3.174 * *$ & 0.602 & 0.630 & -0.617 & $-4.30^{* *}$ & $-71.930 * *$ & $20.363 * *$ \\
\hline $\mathrm{P}_{2} \times \mathrm{P}_{6}$ & -0.313 & -0.678 & $-2.694 * *$ & $-6.110 * *$ & $-17.44 * *$ & $3.02 *$ & -0.103 & 0.093 & -1.121 & $-13.545^{* *}$ & $3.834 * *$ \\
\hline $\mathrm{P}_{3} \times \mathrm{P}_{4}$ & -0.569 & $-3.519 * *$ & $3.185^{* *}$ & $5.929 * *$ & $1.986^{*}$ & 0.325 & $-2.95 * *$ & -0.480 & -1.101 & $-26.795 * *$ & $-7.585^{* *}$ \\
\hline $\mathrm{P}_{3} \times \mathrm{P}_{5}$ & 0.958 & 0.708 & $-6.364 * *$ & $-15.662 * *$ & $-10.61 * *$ & $-3.37 *$ & $4.36^{* *}$ & $-5.04 * *$ & -1.635 & $-23.411 * *$ & $-6.627 * *$ \\
\hline $\mathrm{P}_{3} \times \mathrm{P}_{6}$ & 1.035 & $-3.427 * *$ & $-4.813 * *$ & -0.155 & $1.394 *$ & $-2.22 *$ & 0.623 & $-5.247^{*}$ & $-2.40^{* *}$ & $-25.542 * *$ & $-7.231 * *$ \\
\hline $\mathrm{P}_{4} \times \mathrm{P}_{5}$ & 0.078 & $-3.154 * *$ & -1.039 & -1.058 & $-10.49 * *$ & $-4.19 *$ & 0.250 & 0.231 & $3.126^{* *}$ & $24.238 * *$ & $6.861 * *$ \\
\hline $\mathrm{P}_{4} \times \mathrm{P}_{6}$ & -0.008 & -0.154 & 1.730 & $2.095 * *$ & $2.534 * *$ & -0.161 & 0.373 & 0.208 & $4.253 * *$ & $7.699 * *$ & $2.181 * *$ \\
\hline $\mathrm{P}_{5} \times \mathrm{P}_{6}$ & -0.230 & $2.146^{* *}$ & 0.191 & $18.843 * *$ & $10.205 * *$ & -0.304 & -0.516 & 0.451 & $2.801 * *$ & $25.821 * *$ & $7.309 * *$ \\
\hline S.E.(Sij) & 0.946 & 0.921 & 1.155 & 3.051 & 5.826 & 0.976 & 0.752 & 0.357 & 2.152 & 2.738 & 8.418 \\
\hline
\end{tabular}

ns, ${ }^{*}$ and $* *$ : Non significant, significant at 5 and $1 \%$ levels, respectively.

DT: Days to tasseling, DS: days to silking, DM: days to maturity, PH: plant height, EH: ear height, CL: cob length, CD: cob diameter, NRC: number of rows/cob, NKR: number of kernels/row, NGC: number of grains/cob and GYP: grain yield/plant. 


\section{Specific Combining Ability of the Crosses}

Specific combining ability effects of some crosses showed positive significant performance for many characters under study (Table 3). Among the crosses, $\mathrm{P}_{1} \times \mathrm{P}_{2}$ and $\mathrm{P}_{1} \times \mathrm{P}_{5}$, possessed significant SCA effect for days to tasseling and slking, plant and ear height, number rows/cob, kernels/row, grain number/cob and grain yield/plant exhibited best specific combiner for these characters followed by $\mathrm{P}_{3} \times \mathrm{P}_{5}$ and $\mathrm{P}_{3} \times \mathrm{P}_{6}$ for days to maturity, ear height and two to five of its component characters. The most promising crosses for improving the grain number and grain yield were $\left(\mathrm{P}_{1} \times \mathrm{P}_{2)}\right.$ and $\left(\mathrm{P}_{5} \times \mathrm{P}_{6}\right)$, because it gave the highest positive significant SCA for the above-mentioned characters. High specific combination for grain yield was observed in low $\times$ high general combiners as in the crosses $\mathrm{P}_{1} \times \mathrm{P}_{2}$ and $\mathrm{P}_{2} \times \mathrm{P}_{5}$. The crosses $\mathrm{P}_{4} \times \mathrm{P}_{5}$ and $\mathrm{P}_{5} \times \mathrm{P}_{6}$ were also good for grain yield and involved low $\times$ average general combiners. Results obtained from this study agree with the results obtained by Uddin et al. (2006), Uddin (2008), Alam et al. (2008) and Alam (2009) and Singh et al. (2012). In the study, most of the cases three inbred lines $\left(\mathrm{P}_{1}, \mathrm{P}_{3}\right.$ and $\left.\mathrm{P}_{5}\right)$ exhibited significant positive SCA and possessed comparatively well mean performance, although these parents could be used for developing high yielding hybrids.

\section{CONCLUSION}

Parents with good positive GCA for yield $\left(\mathrm{P}_{1}\right.$ and $\left.\mathrm{P}_{4}\right)$, negative GCA for days to silking and maturity $\left(\mathrm{P}_{1}\right.$ and $\left.\mathrm{P}_{3}\right)$, dwarf plant and ear height $\left(\mathrm{P}_{5}\right)$ may be extensively used in hybridization program as a donor. Better performance of $\mathrm{P}_{1} \times \mathrm{P}_{2}, \mathrm{P}_{1} \times \mathrm{P}_{5}, \mathrm{P}_{3} \times \mathrm{P}_{5}$ and $\mathrm{P}_{3} \times \mathrm{P}_{6}$ can be utilized for developing high yielding hybrid varieties as well as exploiting hybrid vigor. These crosses may be multiplicities for distribution of seeds among the farmers.

\section{Acknowledgments}

The authors are grateful to the financial support of the Ministry of Science \& Information and Communication Technology, Bangladesh for this research work.

\section{REFERENCES}

Alam, A. K. M. M., S. Ahmed, M. Begum and M. K. Sultan. 2008. Heterosis and combining ability for grain yield and its contributing characters in maize. Bangladesh J. Agril. Res. 33(3): 375-379.

Alam, M. S. 2009. Studies on genetic and environmental components of variability in maize (Zea mays L.) Ph. D Thesis, Dept. of Botany, Rajshahi University, Bangladesh.

Amiruzzaman, M., M. A. Islam, K. V. Pixley and M. M. Rohman. 2011. Heterosis and combining ability of CIMMYT's tropical× subtropical quality protein maize germplasm. Int. J. Sust. Agric. 3(3):76-81.

CropStat. 2007. Crop Research Informatics Laboratory, IRRI, The Philipines. 
Griffing, B. 1956. Concept of general and specific combining ability in relation to diallel crossing system. Austrelian. J. Biol. Sci. 9: 463-493.

Haddadi, M. H., M. Eesmaeilof, R. Choukan and V. Rameeh. 2003. Combining ability analysis of days to silking, plant height, yield components and kernel yield in maize breeding lines. African J. Agric. Res. 7(33): 4685-4691.

Jawahar, R. S. 1998. Statistical and biometrical techniques in plant breeding. New Age International (P) Limited, Publishers, New Delhi. pp.205-226.

Keskin, B., H. Akdeniz, I. H. Yilmaz and N. Turan. 2005. Yield and quality of forage corn (Zea mays L.) as influenced by cultivar and nitrogen rate. J. Agron. 4(2): 138-141.

Khalil, I. A., H. Rahman, N. Saeed, N. U. Khan, N. I. Durrishawar, F. Ali and M. Saeed. 2010. Combining ability analysis in maize single cross hybrids for grain yield: A graphical analysis. Sarhad J. Agric. 26(3): 373-379.

Pavan, R., H. C. Lohithaswa, P. Gangashetty, M. C. Wali and B. G. Shekara. 2011. Combining ability analysis of newer inbred lines derived from national yellow pool for grain yield and other quantitative traits in maize (Zea mays L.). Electro. J. Plant Breed. 2(3): 310-319.

Roth, G., D. Undersander, M. Allen, S. Ford, J. Harrison and C. Hunt. 1995. Corn Silage Production, Management, and Feeding. ASA, Madison, WI. NCR574.

Sharief, A. E., S. E. El-Kalla, H. E. Gado, H. A. E. Abo-Yousef, 2009. Heterosis in yellow maize. Aust J. Crop Sci. 3: 146-154.

Singh, P. K. and N. Kumar. 2008. Identification of parents and experimental hybrids in maize. Proceeding of the Tenth Asian Regional Maize Workshop. Makassar, Indronesia, pp.72-73

Singh, P. K., A. K. Singh, J. P. Shahi and R. Rahman. 2012. Combining ability and heterosis in quality protein maize. The Bioscan 7(2):337-341.

Singh, R. K and B. D. Chaudhary. 1985. Biometrical methods in quantitative genetic analysis. Kalyani Publishers, Ludhiana, New Dehli, India, pp. 303-312.

Singh, S. and I. S. Pawar. 2005. Theory and Application of BIOMETRICAL GENETICS. CBS publishers \& Distributers, New Delhi, Bangalore. pp.130-140.

Sprague, GF., LA. Tatum, 1942. General versus specific combining ability in single crosses of corn. J Amer Soci Agron., 34: 923-928.

Uddin, M. S., F. Khatun, S. Ahmed, M. R. Ali and S. A. Begum. 2006. Heterosis and combining ability in corn (Zea mays L.). Bangladesh J. Bot. 35(2): 109-116.

Uddin, M. S., M. Amiruzzaman, S. A. Begum, M. A. Hakim and M. R. Ali. 2008. Combining ability and heterosis in maize (Zea mays L.). Bangladesh J. Genet. Pl. Breed. 21(1): 21-28.

Zaman, M. A. and M. Alam. 2013. Genetic diversity in exotic maize (Zea mays L.) hybrids. Bangladesh J. Agril. Res. 38(2): 335. 